University of Nebraska - Lincoln

DigitalCommons@University of Nebraska - Lincoln

Mammalogy Papers: University of Nebraska

State Museum

Museum, University of Nebraska State

1955

\title{
Mammal Observations at Lower Back River, Northwest Territories, Canada
}

\author{
H. L. Gunderson \\ W. J. Breckenridge
}

J. A. Jarosz

Follow this and additional works at: https://digitalcommons.unl.edu/museummammalogy

Part of the Zoology Commons

Gunderson, H. L.; Breckenridge, W. J.; and Jarosz, J. A., "Mammal Observations at Lower Back River, Northwest Territories, Canada" (1955). Mammalogy Papers: University of Nebraska State Museum. 156. https://digitalcommons.unl.edu/museummammalogy/156

This Article is brought to you for free and open access by the Museum, University of Nebraska State at DigitalCommons@University of Nebraska - Lincoln. It has been accepted for inclusion in Mammalogy Papers: University of Nebraska State Museum by an authorized administrator of DigitalCommons@University of Nebraska Lincoln. 


\section{American Society of Mammalogists}

Mammal Observations at Lower Back River, Northwest Territories, Canada

Author(s): H. L. Gunderson, W. J. Breckenridge, J. A. Jarosz

Reviewed work(s):

Source: Journal of Mammalogy, Vol. 36, No. 2 (May, 1955), pp. 254-259

Published by: American Society of Mammalogists

Stable URL: http://www.jstor.org/stable/1375885

Accessed: $17 / 02 / 201212: 28$

Your use of the JSTOR archive indicates your acceptance of the Terms \& Conditions of Use, available at http://www.jstor.org/page/info/about/policies/terms.jsp

JSTOR is a not-for-profit service that helps scholars, researchers, and students discover, use, and build upon a wide range of content in a trusted digital archive. We use information technology and tools to increase productivity and facilitate new forms of scholarship. For more information about JSTOR, please contact support@jstor.org. 


\section{MAMMAL OBSERVATIONS AT LOWER BACK RIVER, NORTHWEST TERRITORIES, CANADA}

\section{By H. L. Gunderson, W. J. Breckenridge, and J. A. Jarosz}

The Back River drains the interior barrens of the Northwest Territories of Canada. According to Blanchet (1930) the river has its headwaters in a high plateau and flows through a sand plain basin (not in accord with conditions of our base camp). The country north of the Back River drainage is of low relief. The river takes a northerly direction for the last one-third of its course. To the east, between the river and Wager Bay, the country is known to be very rugged.

The first known exploration of the Back River, then called the Great Fish River, was by Sir George Back and his party, who left England in 1833 to search for Sir John Ross. Back's party wintered at Ft. Reliance. During the summer of 1834 they went down the Back River to its mouth and returned to Ft. Reliance where they again spent the winter, returning to England in 1835. In the appendix of Back's report (1836) there is a list of specimens collected and observed. The collecting was done by Mr. Richard King, surgeon to the expedition.

In 1855 Chief Factor James Anderson of the Hudson's Bay Company made a similar journey (Clarke, 1940a) hoping to find traces of the ill-fated Franklin Expedition. Both these exploring trips support Stefansson's statement (1929) that much arctic exploration has been a by-product of search parties.

So far as is known, Back and Anderson and their parties were the only white men who had visited in summer the area selected for the University of Minnesota-Wilkie Foundation expedition to the Back River. Members of the expedition were Dr. W. J. Breckenridge, Harvey L. Gunderson, John A. Jarosz, R. Spence Taylor, Robert J. Wilkie, James W. Wilkie and Dr. Lawrence Larson. The party was in the vicinity of Mount Meadowbank along the Back River from July 13 to August 6, 1953.

Our camp was located at an elevation of about 150 feet above sea level on a bay of the Back River at $66^{\circ} 10^{\prime} \mathrm{N}$. latitude and $96^{\circ} 57^{\prime} \mathrm{W}$. longitude, about 125 miles northwest of Baker Lake. The topography in the vicinity of camp was undulating with many high hills. The highest of these was Mount Meadowbank with an altitude of $\mathbf{5 7 0}$ feet. Some of the hills were composed of metamorphosed rock outcrops, others of rubble dumped by retreating glaciers, and eskers of many miles in length were not uncommon. The surface of the hills was covered with material ranging in size from gravel to desk-sized boulders, most often one or the other, rarely both.

Those valleys and depressions not filled with water, had carpets of sedge and moss-covered peaty tussocks. There were innumerable small lakes. Two factors cause poor drainage in the Barren Grounds. One is the presence of permafrost, the other is that the youth of the land has not yet allowed for the development of permanent stream and river valleys, with the exception of the large rivers. Arctic soils are generally acidic because of this poor drainage and poor aeration. Organic decay by bacterial action is extremely slow due to the low temperatures. Consequently, nitrogen and salts needed by plants are rather scarce. 
The plant communities of the camp area could be fitted into two categories: the rock desert and the tundra communities of Porsild's (1951) classification. The rock desert communities were found on the rock surfaces of hills and rocky slopes. Various species of crustose lichens and a few of the black foliose lichens covered the rocks. Where some soil had accumulated, there were such plants as moss pink (Silene acaulis), saxifrage (Saxifraga tricuspidata), arctic poppy (Papaver radicatum), crowberry (Empetrum nigrum), broad-leaved willow herb (Epilobium latifolium), cotton grass (Eriophorum sp.) and other grasses and sedges.

According to Porsild (1951) the tundra community differs from the rock desert community in that the tundra community has a closed or continuous cover of vegetation. This was true of the valley and wetter places where there were such species as ground birch (Betula glandulosa), Labrador tea (Ledum decumbens), bear berry (both Arctostaphylos alpina and A. rubra), white heather (Cassiope tetragona), fernweeds (Pedicularis sp.) and grasses, sedges, lichens and mosses.

Temperature readings were taken every two hours, when time permitted, from July 15 to August 6 . Minimum-maximum thermometer readings were recorded from July 20 through July 29 and on August 4, 5 and 6. Notations concerning precipitation, cloudiness and wind direction and velocity were recorded daily.

The lowest temperature recorded was $34^{\circ}$ on July 23 and the lowest average daily temperature was $45^{\circ}$ on July 28 . The highest temperature tallied was $77^{\circ}$ at noon on August 3 . The highest daily average, $62^{\circ}$, was recorded on August 5. The greatest daily variation recorded was $33^{\circ}\left(43^{\circ}-76^{\circ}\right)$ on August 4. Precipitation occurred on 8 days, but it was so light that it was measurable only on 4 days when $5 / 16,5 / 16,1 / 8$, and $1 / 16$ inches fell, for a total of $13 / 16$ inch. Winds of 25-38 miles per hour (estimated from the Beaufort scale) were recorded on 2 days.

The original plan for the mammal work was to take enough traps to maintain a trap line of about 400 snap traps and 50 live traps. Because of weight and space restriction of air travel the live traps could not be taken, and several hundred snap traps were lost during field work near Churchill. Mr. Cecil Law of the Defense Research Board at Ft. Churchill loaned as many traps as he could spare. This loan made a total of 105 small snap traps, 8 rat traps, and 6 jump traps (No. 1). Some traps were left unbaited, others were baited with rolled oats, peanut butter or dehydrated apples. So few specimens were caught that bait preference data would not be worthwhile interpreting. So far as mammals were concerned, the Barren Grounds seemed aptly named.

A few specimens were lost when the plane carrying the Wilkie brothers and Lawrence Larson back to Churchill was forced down on Lake Kaminuriak.

\section{ACCOUNTS OF SPECIES}

Ursus arctos horribilis. Barren Grounds grizzly.-We did not see any evidence of grizzly bears in the camp area. Mr. A. Lunan of the Hudson's Bay Post at Baker Lake, which serves the Eskimos of the Thelon River and of the Back River to the north, said that Eskimos do occasionally bring in skins of grizzly bears. Regarding the scientific name of the grizzlies in this area, Rausch (1953) believes, "At present it seems best to use the name Ursus arctos horribilis for the grizzlies of northern Canada and mainland Alaska." 
Mr. Lunan told of having several bearskins brought to the post that were smaller than grizzlies and smoky in appearance. Could this possibly be a glacier bear, a color phase of the black bear? Black bears, which are numerous up to tree line, are sometimes found out on the barrens.

Alopex lagopus. Arctic fox.-An arctic fox den was found about $31 \frac{1}{2}$ miles west of camp. The burrows occupied the greater part of a pear-shaped, gravelly knoll, which varied from three to ten feet in height. This mound, possibly the remnant of an esker, was about twentyfive yards in diameter at the large end and about 60 yards in length.

The mound was covered with a luxurious growth of vegetation, mostly grasses, of which Calamagrostis neglecta was most abundant. Other common grasses were Calamagrostis inexpansa, Poa arctica, Hierochloa alpina, and Alopeucurus alpinus. Two other plants which were fairly common on the mound were Taraxacum lacerum and an arctic variety of Equisetum arvense. As previously mentioned, there is a definite lack of nitrogen and salts in arctic soils. The addition of fertilizers resulting from the remains of food material and excrement, and the addition of nitrates from the urea accounted for the increased vegetation of the mound.

In the center of the mound there was a bare gravel area about five feet across, where an adult would keep watch, or at times lie down. It probably served as a "watch post" from which it could observe enemies approaching, or scan the surrounding meadow for prey. Parry's ground squirrels occupied this meadow, and several times they were observed at the opposite end of the mound from the watch post. Some small burrows here were apparently those of the ground squirrels, but whether permanently or sporadically occupied could not be determined.

The mound could be approached to within 100 yards before the adult would disappear into a burrow. Only one adult, never two, were seen at a time. There were three young. We could hear the kits barking within the burrows when we were on the mound. They apparently remained within the burrow until called out by an adult. At one time we set traps at the den when no adult was present. After setting the traps we retreated to a high hill to watch. After two hours and fifteen minutes, an adult approached, went to the "watch post," sniffed the air in several directions, examined the traps, walked back and forth several times, and not until then did the kits appear on the surface.

At one time we found a freshly killed Parry's ground squirrel cached away and partly covered over, about fifty yards from the den. The ground squirrel was covered with saliva around the neck and head and had apparently been recently cached by the fox, probably when it was disturbed by us. At another time a collared lemming was found on a wellworn path leading up the side of the mound. The lemming, too, was wet with saliva and had evidently been dropped by the adult fox on finding us near the den.

The scats around the den contained a great deal of hair of Parry's ground squirrel and the skulls of lemmings. There were also remains of caribou bones. One eight-inch piece of caribou femur, lying near the watch post, was well worn with tooth marks and probably served as a "toy" for the kits. An unusual food item was a piece of skin from an arctic char (Salvelinus subalpinus). At higher water levels arctic char could possibly have come up the stream near the mound, but at the time we were there the fox would have had to travel at least three-quarters of a mile to get the fish. At another arctic fox den about 12 miles south of camp, ptarmigan (possibly rock ptarmigan) feathers and the foot of an immature arctic hare were found. Probably the major food item of the arctic fox at the time we were in the area was the Parry's ground squirrel.

At least 10 weathered skulls of arctic foxes were found near our camp. Most likely these were an accumulation from the previous trapping activities of Eskimos who had lived at the unoccupied site near our camp.

Two immature male arctic foxes were collected. The last one collected on August 5 weighed $41 / 2$ pounds and measured $718 \mathrm{~mm}$. and was probably nearly full grown. The other, collected on July 21 , weighed $31 / 2$ pounds and measured $612 \mathrm{~mm}$. The color patterns matched the descriptions given by Preble (1902) for the summer pelage of the young.

There are few descriptions of the summer pelage of arctic fox. We were surprised at the 
pattern of dark (seal brown to gray) head, back, base of tail dorsally and extending down the outer side of the legs contrasting with the light fawn of the sides, underparts and ventral surface of the tail. Neither Merriam (1902) nor Preble (1902) mentioned a characteristic small patch of white hairs on the dorsal side of the tail about a quarter of the way out from the base, which we found conspicuous at a distance. We do not know whether this was a character of the few individuals we saw or whether it is typical of all arctic foxes.

Canis lupus. Arctic wolf.-The tracks of an arctic wolf were seen in wet sand about a mile west of camp. Two arctic wolf skins were examined at an Eskimo camp about thirty miles from camp. Both specimens were very light, almost white. The larger of the two specimens was purchased but was lost in the plane accident.

Citellus parryi. Parry's ground squirrel.-These ground squirrels were commonly seen but were most numerous in sandy areas and along eroded banks. Again, as was the case with the fox den, the mounds and other areas of concentrated burrows supported a luxurious growth of vegetation.

At the time we arrived at the Back River the young appeared to be at least half-grown and were no longer segregated into family groups. The young and adults did not seem to mix but this might have been due to the wariness of the adults who were also more solitary, whereas the young were more often seen in small groups. Both young and adults travelled greater distances than do most of the ground squirrels of temperate regions with which we are familiar. One young travelled from a burrow mound to a bank about 200 yards distant. An adult travelled over 400 yards in a straight line.

The ground squirrels fed on seeds of grasses, sedges, willows, and, in one instance, bear berry. Grass seeds were procured in several ways. The animal took one species of grass (Poa arctica) by the stalk in the front paws and ran the stalk through its mouth, stripping off the seeds. Other grasses, Hierochloa alpina and Calamagrostis inexpansa, were eaten seed by seed. Leaves of arctic avens (Dryas integrifolia) also were taken.

One immature ground squirrel, taking a nap in the sun, curled up in an upright position, sitting on his hind feet with his head and front legs tucked under himself. This is the posture so often taken by other species of ground squirrels during hibernation.

The ground squirrels collected the last week of July were extremely fat, particularly a young one. Allee, et al. (1949) wrote on page 105, "Where the soil is permanently frozen beneath the level reached by summer thaws, hibernation of burrowing mammals cannot take place, and hence is absent in polar regions." At first glance this may seem logical, yet Parry's ground squirrels do hibernate. While many references have been made to hibernating Parry's ground squirrels in the past literature starting as far back as Richardson, actual research on the physiology has been done only recently. The two most recent articles are Wilber and Musacchia (1951) and Musacchia and Wilber (1952), working on hibernating ground squirrels at Point Barrow, Alaska.

Mayer (1953) wrote, "Even in the arctic, however, a relatively low permafrost table exists in certain areas correlated with good drainage, and within these restricted regions ground squirrels have a suitable habitat. Thus, though the coastal plain is flat. . the squirrels may locate their burrows in the ridges and river sandbanks, hillocks and other raised areas with a sandy soil, sandy loam soil or sandy clay soil." Gavin (1945) wrote concerning the Parry's ground squirrel, "Abundant in the sandy country at the mouths of rivers and along the coast where burrowing is easy." Hanson (unpublished ms.) wrote, "In instances where their burrows lay close to the river banks, [in early spring] they had to tunnel up through five to six feet of snow before reaching the surface." Even with the light snowfalls in the Barren Grounds, deep drifts accumulate below protecting banks, and it is probable that the burrowing along such banks, together with the protection of the snowdrifts, makes hibernation possible.

Lemmus trimucronatus. Brown lemming.-Brown lemmings either were not very abundant or did not get into the traps readily. Twenty six were caught in 1898 trap nights to give a trap-night figure of .014 . Seven adults and 18 immatures were caught. All adult specimens were lost in the plane accident. The first young were caught on July 23 (trapping started July 16). During the first part of the season, no brown lemmings were caught in fifty traps 
set in a boggy area of sphagnum hummocks and willows, but they began appearing in these same traps on July 24 . This seemed to indicate a movement into an area which earlier had most likely been too wet.

Dicrostonyx groenlandicus. Collared lemming.-Only four collared lemming were caught in 1898 trap nights giving a figure of .002 . There were two adults and two young. The two adults weighed 49.6 and 57.1 grams. Another specimen was found at the arctic fox den. The collared lemming were taken in the higher and drier communities, called "rock desert communities" by Porsild (1951). None were taken in the boggy areas. It would appear that the two genera of lemming are ecologically separated, the collared lemming found in drier areas and the brown lemming in wetter areas.

The populations of the collared lemming were obviously very low. Shelford (1943) estimated the magnitude of population fluctuations (at Churchill, Manitoba) as from 6 to 7 individuals per 250 acres to 4,000 individuals per 250 acres.

Lepus arcticus. Arctic hare.-Only four arctic hares were seen by the entire party at the Back River. An adult male, in gray pelage, was collected and weighed $61 / 2$ pounds. Mr. A. Lunan of Baker Lake said that arctic hares have been very scarce the last few years.

Rangifer arcticus. Barren Ground caribou.-No caribou were seen near our campsite, but a few tracks considered to be fresh were observed. In the saddle of a hill several hundred yards west of camp were tent rings and rock mounds of an old Eskimo campsite. Here there were many caribou bones. All of the long bones were broken, showing the Eskimos had used them for food. At the Eskimo camp about thirty miles down river, there were many caribou bones and pieces of skin lying on the ground and three stone caches which apparently contained caribou. By one partly opened cache there were many pieces of caribou skin and bones. One Eskimo family lived in a tent made of caribou skins.

Caribou bones were found at some rough-legged hawk nests and also at the arctic fox den. There was a recent caribou crossing near Sinclair Falls where a thick mat of caribou hair lined the south side of the Back River for a distance of nearly a hundred yards. River level records indicated the herd had crossed 3 to 4 weeks before or early in July. According to Banfield's (1951) maps, there would not be many caribou in the vicinity of our camp at any season.

Ovibos moschatus. Muskoxen.-The only evidence of muskoxen was the weathered part of a skull found near the campsite. George Back (1936), the first white man to explore the river, observed in 1834, "Both sides [of the river] were hemmed in by mountains . . . the green shelving slopes dotted with herds of musk oxen." At noon of the same day, "A glimpse of the sun . . . gave the latitude of $66^{\circ} 6^{\prime} 24^{\prime \prime} \mathrm{N}$; nearly abreast of a picturesque and commanding mountain . . . where cattle were feeding . . . and I called the hill Mount Meadowbank. ..." The term "cattle" without much doubt refers to muskoxen. Anderson followed the Back River in 1855 and wrote (from Clarke, 1940a), "One third this day nearly lost by our mistaking a channel of the river . . . [probably the Meadowbank]. Two large bands of musk oxen were seen just before encamping." From these reports muskoxen must have been fairly numerous in the area in earlier times. But they evidently suffered the fate of a fad for muskoxen robes that followed the disappearance of buffalo. The hunting of muskoxen for the robes probably reached its height somewhere about 1913. At any rate, they have disappeared from the area and Clarke (1940b) wrote, "None of the Back River or Meadowbank River Eskimos have reported any muskoxen for a number of years."

\section{LITERATURE CITED}

Alles, W. C. et al. 1949. Principles of animal ecology. W. B. Saunders, Philadelphia. $837 \mathrm{p}$.

BACK, G. 1836. Narrative of the arctic land expedition to the mouth of the Great Fish River, and along the shores of the Arctic Ocean in the years 1833, 1834, and 1835. E. C. Carey and H. Hart, Philadelphia.

Banfield, A. W. F. 1951. The Barren-ground caribou. Dept. Resources and Development. Ottawa, Canada.

Branchet, T. H. 1930. Keewatin and northeastern Mackenzie. Dept. Interior, Ottawa, Canada. 
Clarke, C. H. D. 1940a. Chief factor James Anderson's Back River Journal of 1855. Canadian Field Nat. 54: 134 and 55: 9, 1941.

1940b. A biological investigation of the Thelon Game Sanctuary. Canada. Nat. Mus. Bul. No. 96, Biol. Ser. No. 25.

$\rightarrow$ Gavin, A. 1945. Notes on mammals observed in the Perry River District, Queen Maud Sea. Jour. Mamm., 26: 226-230.

Hanson, H. C. Unpublished report of the Perry River Expedition.

KING, R. 1836. Appendix 6, pp. 590-594 of Narrative of a journey to the shores of the Arctic Ocean in 1833, 1834, and 1835 under the command of Captain Back. R. N. London, R. Bentley.

Mayer, W. J. 1953. Preliminary study of the barren ground squirrel, Citellus parryi barrowensis. Jour. Mamm., 34: 334-345.

Merriam, C. H. 1902. Four new arctic foxes. Proc. Biol. Soc. Washington, 15: 170-174.

$\rightarrow$ Musacchia, X. J. and C. G. Wilber. 1952. Studies on the biochemistry of the arctic ground squirrel. Jour. Mamm., 33: 356-362.

Preble, E. A. 1902. A biological investigation of the Hudson Bay region. North Amer. Fauna No. 22.

Porsild, A. E. 1951. Plant life in the arctic. Nat. Mus. Canada. Ottawa, Canada. 27 p.

RAUSCH, R. 1953. On the status of some arctic mammals. Arctic, 6: 91-148.

Shelford, V. E. 1943. The abundance of the collared lemming (Dicrostonyx groenlandicus (Tr.) var. richardsoni Mer) in the Churchill area, 1929 to 1940. Ecology, 24: 472-484.

$\rightarrow$ Wilber, C. G. AND X. J. Musacchis. 1950. Fat metabolism in the arctic ground squirrel. Jour. Mamm., 31 : 304-309.

Minnesota Museum of Natural History, University of Minnesota, Minneapolis. Received June 10, 1954.

\section{RATS OF ARNO ATOLL, MARSHALL ISLANDS}

\section{By Joe T. Marshall, Jr.}

The following information on rats was recorded during the summer of 1950 as part of a study I made on land vertebrates of Arno Atoll, Marshall Islands while a member of a party sent by the Pacific Science Board of the National Research Council, supported by the Office of Naval Research, to study the ecology of a typical low coral atoll. Most of the observations are of undisturbed rats; others were flushed from hiding places, and a few were collected: 17 Polynesian rats, Rattus exulans (of which eight are preserved at the U.S. National Museum), and two black rats, $R$. rattus (both at the museum). I am grateful to David $\mathrm{H}$. Johnson of that museum for confirming the identifications of these specimens, to Lee Douglas for examining the tapeworms, and to Lois Taylor for care of the preserved helminths and caecal protozoa. The Arnoese people are very hospitable, and they extended numerous courtesies as well as technical assistance-such as the identification of plants by Mr. Konto. These people are notable for their extended knowledge of, and intelligent interest in natural history. Kijirik is their word for rat.

Although the common name "black rat" is used here for the species $R$. rattus, it should be understood that, in the Pacific at least, the several named color phases may be found in the same litter.

Arno's five square miles, all under 12 feet high, are disposed in numerous small 